\title{
Tl sequestration in the middle part of the Allchar Sb-As-Tl-Au deposit, North Macedonia
}

\author{
TAMARA ĐORĐEVIĆ ${ }^{1}$, UWE KOLITSCH ${ }^{1,2}$, PETR \\ DRAHOTA $^{3}$, JURAJ MAJZLAN ${ }^{4}$, MAGDALÉNA PEŘESTÁ ${ }^{3}$, \\ GORAN TASEV $^{5}$, TODOR SERAFIMOVSKI ${ }^{5}$, IVAN BOEV $^{5}$ \\ AND BLAŽO BOEV 5 \\ ${ }^{1}$ Universität Wien \\ ${ }^{2}$ Naturhistorisches Museum \\ ${ }^{3}$ Faculty of Science, Charles University \\ ${ }^{4}$ University Jena \\ ${ }^{5}$ University "Goce Delčev" \\ Presenting Author: tamara.djordjevic@univie.ac.at
}

In geogenic Tl-extreme environments, such as Tl-rich sulfide deposits, secondary $\mathrm{Tl}$ minerals play a crucial role in the mobility and fate of this toxic element.

In the middle part of the Allchar Sb-As-Tl-Au deposit, there is a prevalence of $\mathrm{Sb}$ mineralization accompanied by As and very minor $\mathrm{Tl}, \mathrm{Ba}, \mathrm{Hg}$ and $\mathrm{Au}$. We used PXRD, SEM-EDS, Raman spectroscopy, pore-water analysis and chemical extractions to determine the distribution and speciation of $\mathrm{Tl}$ in the As- and Sbrich waste dumps and associated soils (As: $3.8-17.7 \mathrm{~g} / \mathrm{kg}$; Sb: $0.9-16.4 \mathrm{~g} / \mathrm{kg}$ and $\mathrm{Tl}: 127-837 \mathrm{mg} / \mathrm{kg}$ ). Soil samples and wastedump material are composed mostly of dolomite, quartz, gypsum, pyrite, marcasite, stibnite, realgar and baryte, followed by muscovite, kaolinite-group minerals and various metal-Sboxides. The $\mathrm{Tl}$ sulfosalts fangite, lorándite and pierrotite are the primary Tl-sources and are mostly hosted in realgar. Thallium dissolved during weathering under circumneutral conditions is reprecipitated as As-bearing (0.55-6 at.\% of As) avicennite, crystallizing in massive aggregates up to $200 \mu \mathrm{m}$ in length, and as tiny, fibrous Tl-bearing todorokite- or birnessite-type Mn oxides (up to 8.5 at.\% of $\mathrm{Tl}$ ) intergrown with avicennite and dolomite. Furthermore, tiny spherulitic aggregates (up to $3 \mu \mathrm{m}$ ) of a Tl-Sb-oxide (Tl:Sb 3:1) (unknown mineral species) have been found intergrown with quartz, muscovite and minor dolomite. In contrast, thallium dissolved during weathering under acidic conditions ( $\mathrm{pH} \sim 2.8-3.1$ ) did not reprecipitate at all. In such samples jarosite-group minerals, scorodite, tripuhyite and hydroxycalcioroméite crystallised.

The pore water (pH: 2.8-7.8) contained large aqueous concentrations of Sb (up to $14 \mathrm{mg} / \mathrm{l}$ ), As (up to $8.5 \mathrm{mg} / \mathrm{l}$ ) and $\mathrm{Tl}$ (up to $464 \mu \mathrm{g} / \mathrm{l}$ ). Mild extractions mobilised up to $25 \%$ of the total $\mathrm{Tl}, 3 \%$ of the total $\mathrm{Sb}$ and $11 \%$ of the total As, indicating that a large fraction of $\mathrm{Tl}$ is weakly bound and could be easily mobilised into the surrounding ecosystems.

The identification of avicennite, Tl-Mn oxides and Tl-Sb oxides in near-neutral soils points to their stability at near-neutral soil $\mathrm{pH}$ and indicates their potential for the immobilisation of toxic $\mathrm{Tl}$ in various contaminated environments.

Financial support of the Austrian Science Fund (FWF) (P 30900-N28) is gratefully acknowledged. 